\title{
PERAN MEKANISME GOOD CORPORATE GOVERNANCE TERHADAP KINERJA KEUANGAN PERBANKAN YANG TERDAFTAR DI BURSA EFEK INDONESIA
}

\author{
Liyandri R. Tarigan \\ Chatarina Yekti Prawihatmi \\ ceciliatarigan@yahoo.com \\ yekti@unika.ac.id
}

Fakultas Ekonomi dan Bisnis Unika Soegijapranata,Semarang, Indonesia

\begin{abstract}
Info Artikel
Sejarah Artikel:

Diterima

Disetujui

Dipublikasikan

Keywords:

GoodCorporate

Governance;

financial

performance;

board of directors;

size of board of

commissioners;

independent

commissioners.

Abstrak

Begitu banyak penelitian terdahulu mengenai pengaruh Good Corporate Governance terhadap kinerja keuangan menunjukkan hasil yang bervariasi. Hal ini menarik untuk menguji konsistensi hasil penelitian sebelumnya dan memperoleh bukti empiris ada tidaknya pengaruh Good Corporate Governance terhadap Kinerja Keuangan Perbankan yang terdaftar di Bursa Efek Indonesia. Semakin membaiknya sektor perbankan di picu pula dengan munculnya surat edaran Bank Indonesia tahun 2013 tentang pelaksanaan Good Corporate Governance dapat di asumsikan bahwa penerapan GCG dalam di sektor perbankan juga akan semakin baik, dan dapat disetarakan dengan GCG dalam ASEAN sehingga akan mendukung dalam implementasi MEA. Variabel bebas yang mewakili GCG adalah jumlah dewan direksi, ukuran dewan komisaris, komisaris independen dan ukuran perusahaan. Penelitian ini memilih periode penelitian 2012-2015 untuk melihat apakah perusahaan khususnya perbankan semakin siap dalam menghadapi MEA 2015. Hasil penelitian menunjukkan bahwa Jumlah Direksi tidak berpengaruh terhadap Kinerja keuangan perbankan. Dewan Komisaris tidak berpengaruh terhadap Kinerja keuangan Perbankan. Sesuai dengan teori, komisaris independen dan ukuran perusahaan berpengaruh terhadap kinerja keuangan perbankan.
\end{abstract}




\begin{abstract}
Many previous studies regarding the effect of Good Corporate Governance on financial performance have varied results. It is interesting to test the consistency of the results of previous studies and obtain empirical evidence whether or not the influence of Good Corporate Governance on Banking Financial Performance is listed on the Indonesia Stock Exchange. The improvement in the banking sector was also triggered by the emergence of the 2013 Bank Indonesia circular letter regarding the implementation of Good Corporate Governance. It can be assumed that the implementation of GCG in the banking sector will also be better, and can be balanced with GCG in ASEAN so that it will support MEA implementation. The independent variable representing GCG is the number of board of directors, the size of the board of commissioners, independent commissioners and company size. This study chose the 2012-2015 research period to see whether companies, especially banks, were better prepared to face the 2015 MEA. The results of the study showed that the number of Directors did not affect banking financial performance. The Board of Commissioners has no effect on Banking financial performance. In accordance with the theory, independent commissioners and company size influence the financial performance of banks.
\end{abstract}

\title{
PENDAHULUAN
}

Menurut Otoritas Jasa Keuangan (2014) upaya pengawasan terhadap perusahaan pada sektor keuangan dapat diwujudkan dengan adanya implementasi praktik tata kelola perusahaan atau Good Corporate Governance (GCG) . Pengawasan GCG yang diterapkan pada perusahaan diharapkan dapat meningkatkan kinerja perusahaan baik secara finansial maupun operasional. Perusahaan yang melaksanakan GCG akan memberikan dampak yang positif bagi perusahaan salah satunya akan dapat meningkatkan kesejahteraan pemilik atau pemegang saham melalui menaikkan nilai 
perusahaan di mata investor. GCG juga dapat mempermudah diperolehnya dana pembiayaan yang lebih murah menurut Forum Corporate Governance in Indonesia (FCGI). GCG juga mendorong semua faktor internal dan eksternal dalam perusahaan agar lebih baik dalam menjalankan manajemennya. GCG juga kunci sukses perusahaan untuk menghasilkan keuntungan dan tetap bertahan dan bertumbuh.

Salah satu latar belakang yang ada dalam GCG adalah "Agency Theory" hal ini muncul ketika pemilik perusahaan memberikan wewenang kepada "professional managers" dan memiliki beda kepentingan. Munculnya dilema ini disebabkan dari pemilik yang ingin perusahaan terus berkembang dan bertumbuh melalui ekspansi atau berupaya agar perusahaan tetap terus bertahan. Disisi lain manajer ingin perusahaan mendapatkan profit yang sebesar besarnya sedangkan manajer memiliki informasi perusahaan yang "mungkin" tidak dimiliki pemilik. Hal ini banyak memberi dampak kurang baik bagi perusahaan salah satunya menghilangkan kepercayaan investor dan dapat berpengaruh ke kinerja perusahaan.Contoh yang telah terjadi adalah dalam dunia perbankan adalah kasus Bank Bali Indonesia tahun 1997 hal yang terjadi adalah manajer Bank Bali Indonesia mendanai sebuah partai politik tertentu dengan mengalihkan dana Investasi.

Mengingat semakin pentingnya penerapan Good Corporate Governance dilakukanlah Kebijakan Reformasi Perbankan pada maret 1999 dengan melakukan penutupan Bank, pengambilalihan 7 bank, rekapitulasi 9 bank. Sehingga bank yang tersisa sebanyak 151 bank. Selain melaksanakan reformasi dikeluarkanlah API (Arsitektur Perbankan Indonesia) didalamnya terdapat 6 pilar utama dan salah satunya adalah menciptakan corporate governance untuk memperkuat kondisi internal perbankan nasional pada tahun 2007. Hal yang menjadi salah satu pemicu maraknya lagi GCG di Indonesia salah satunya setelah munculnya kasus Bank Century dan ini menunjukkan bahwa betapa penting dan dibutuhkannya penerapan Corporate Governance yang baik.

Kondisi Perbankan di Indonesia terus mengalami perbaikan dapat dilihat di data menurut bank Indonesia tercatat pada tahun 2012 inflasi tertinggi berada di 8,38\% berbeda ketika tahun 2008 inflasi mencapai 12,305\%. Sedangkan pada tahun 2012-2015 inflasi terendah berada di tahun Januari 2012 mencapai 3,65\% terus mengalami 
fluktuasi tetapi tidak melebihi ketika inflasi di tahun 2015. Likuiditas perbankan kembali menunjukkan perbaikan selama empat bulan berturut-turut yang terlihat dari penurunan LDR sistem perbankan hingga mencapai 89,5\% pada Oktober 2014. Iklim suku bunga yang tinggi membawa pengaruh positif bagi pertumbuhan simpanan perbankan. Di sisi lain, melemahnya prospek bisnis menyebabkan pertumbuhan kredit mengalami perlambatan. Bank Indonesia (BI) pada 15 Januari 2015 mempertahankan bunga acuan BI rate di 7,75\%. Kebijakan ini dinilai masih konsisten dengan upaya untuk mengarahkan inflasi ke targetnya di 4\%-1\%. Pada kenyataan hingga bulan april 2016 posisi Bi Rate mampu turun dan mencapai 6,75\% di bulan maret 2016 (bi.go.id). Membaiknya sektor perbankan dengan implementasi GCG di Indonesia dapat sejajar dengan implementasi GCG di Negara Asean dalam menyambut Masyarakat Ekonomi Asean tahun 2015.

Untuk mencapai tata kelola perusahaan yang baik bagi perbankan maka dibutuhkan sistem mekanisme cara kerja tersistem. Mekanisme Tata Kelola Perusahaan adalah sebuah aturan main, prosedur dan hubungan yang harus jelas antara semua pihak yang terlibat dalam pengambilan keputusan dengan baik yang melakukan control/pengawasan terhadap keputusan tersebut (Walsd dan Seward,1990 dalam Arifin 2005). Pengawasan tata kelola tersebut dibagi menjadi dua kelompok besar yaitu Internal dan Eksternal Mechanism.Internal Mechanism, mengendalikan perusahaan dengan struktur dan proses internal seperti rapat shareholder, komposisi dewan direksi, dewan komisaris. External mechanism, pengendalian melalui perusahaan dan mekanisme pasar. Penelitian ini mengukur tata kelola perusahan melalui mekanisme tata kelola perusahaan seperti mekanisme internal melalui variabel ukuran dewan komisaris, komisaris independen, jumlah direksi sedangkan mekanisme eksternal melalui rasio kecukupan modal (CAR)

Menurut surat edaran yang dikeluarkan oleh Bank Indonesia kepada semua bank umum konvensional di Indonesia tahun 2013 mengatakan bahwa sehubungan kewajiban bank untuk menilai sendiri tingkat kesehatan bank baik individual maupun konsolidasi mencakup pula Good Corporate Governance dan bank wajib untuk menyampaikan laporan pelaksanaan GCG dan bagi bank yang memiliki homepage wajib menginformasikannya. Kinerja perbankan selalu berakitan dengan tingkat kesehatan 
perbankan. Metode tingkat kesehatan perbankan ini dikenal sebagai CAMEL ini berisi aspek permodalan, kualitas asset, rentabilitas, likuiditas, dan solvabilitas yang sudah ditetapkan standar ketentuannya dalam Bank Indonesia. Dalam hal ini Bank Sentral mengeluarkan regulator bahwa yang mempengaruhi kinerja perbankan terutama dalam probabilitas melalui persyaratan cadangan dan atau Rasio Kecukupan Modal (CAR). Penilaian kinerja bank memang hal yang penting, bank yang menjaga kinerjanyaakan mampu membagi dividennya maka akan menaikkan nilai saham sehingga hal ini dapat berarti naiknya kepercayaan masyarakat terhadap bank bersangkutan. Kondisi tinggi atau rendahnya ROA mengindikasikan seberapa besar efisiensi penggunaan modal dan turun naiknya pendapatan.

Penelitian yang dilakukan Sukamulja, 2004 menggunakan variabel dependennya adalah ROA dan Tobin's Q yang diproksikan dengan variabel independen ukuran perusahaan dan ukuran dewan komisaris. Hasil dari penelitian ini adalah kedua variabel tersebut (ukuran perusahaan dan ukuran dewan komisaris) adalah berpengaruh terhadap ROA. Sedangkan penelitian Irmalasari (2010) yang menggunakan variabel dependen ROA dan diproxikan dengan variabel independen ukuran perusahaan, ukuran dewan komisaris, jumlah direksi, komisaris Independen, kepemilikan asing, pemegang saham pengendali, kepemilikan pemerintah, CAR, Auditor eksternal. Hasil dari penelitian ini membuktikan bahwa yang berpengaruh dengan ROA hanya ukuran dewan direksi, CAR, auditor eksternal sedangkan variabel ukuran perusahaan dan ukuran dewan komisaris tidak berpengaruh terhadap ROA. Ukuran perusahaan menggambarkan kemungkinan mencapai skala ekonomis disisi perbankan, ukuran perusahaan dapat menggambarkan kekuatan pasar bank bersangkutan (Oktapiyani,2009). Bank yang memiliki ukuran yang besar biasanya memiliki masalah keagenan yang cukup besar pula karena sulit untuk dimonitoring sehingga harus menambah dewan komisari karena membutuhkan pengawasan yang lebih.

Dalam penelitian Klapper dan Love tahun 2002 menggunakan ROA sebagai variabel dependen dan variabel independen nya pengukuran CGI, ukuran perusahaan, dan rata rata pertumbuhan penjualan. Hasil dari penelitian ini membuktikan bahwa ketiga variabel independen (Pengukuran CGI, Ukuran perusahaan, Rata rata pertumbuhan penjualan) berpengaruh signifikan terhadap ROA. Penelitian yang 
dilakukan oleh Christiawan (2015) dengan menggunakan variabel dependen ROA dan independen ukuran perusahaan, ukuran dewan komisaris, komisaris independen, dan keputusan manajerial. Hasil dari penelitian ini adalah komisaris independen dan ukuran perusahaan berpengaruh negatif signifikan terhadap ROA tetapi variabel dewan komisaris dan kepemilikan manajerial tidak berpengaruh terhadap ROA

Penelitian-penelitian yang telah dilakukan menunjukkan adanya inkonsistensi hasil dimana terdapat perbedaan pengaruh antar variabel bebas terhadap kinerja keuangan Perbankan. Hal ini membuat diperlukan adanya pengujian untuk menganalisis pengaruh Jumlah direksi, ukuran dewan komisaris, komisaris independen, terhadap Return On Assets sebagai alat ukur kinerja keuangan dan ukuran perusahaan sebagai variabel kontrol. Menurut Mayur dan Saravanan, 2008 dalam Oktapiyani, 2009 Size dapat menggambarkan kekuatan pasar dari bank yang bersangkutan. Bank yang besar akan memiliki masalah keagenan yang besar pula sehingga perlu dilakukan pengawasan dengan menambah dewan komisaris, komisaris independen, ataupun jumlah direksi. Di sisi lain perusahaan yang besar justru memiliki peraturan dan tata kelola yang terstruktur, sehingga Size dapat digunakan sebagai variabel kontrol antara mekanisme GCG dan kinerja keuangan.Penelitian yang dilakukan oleh Faiza Nur Rohmah (2013) yang menyatakan bahwa ukuran perusahaan berpengaruh terhadap kinerja keuangan. Ukuran perusahaan merupakan kekuatan finansial yang dimiliki oleh sebuah perusahaan dimana semakin besar aset yang dimiliki oleh perusahaan maka akan semakin mendapat perhatian di mata masyarakat. Besarnya aset yang dimiliki oleh perbankan dapat dilihat dari banyaknya kantor cabang, banyaknya dividen yang dibagikan kepada pemegang saham yang secara otomatis menciptakan citra dan reputasi yang baik di mata masyarakat. Dengan begitu, perusahaan akan termotivasi untuk selalu mempertahankan kinerjanya yaitu kinerja keuangannya. Hasil penelitian Raharja (2012) dan Ayu Permata (2014) justru membuktikan bahwa ukuran perusahaan tidak berpengaruh terhadap kinerja keuangan perusahaan, ukuran perusahaan yang besar belum tentu menghasilkan kinerja keuangan_yang lebih baik. Semakin besar aset yang dimiliki perusahaan, semakin kompleks pula masalah agensi yang dihadapi.

Menurut Bringham \& Houston (2006) para manajer diberi kekuasaan oleh pemilik perusahaan, yaitu pemegang saham, untuk membuat keputusan, dimana hal ini, menciptakan potensi konflik kepentingan yang dikenal sebagai teori keagenan (agency 
theory). Hal ini menjadi sebuah dilema yang banyak terjadi di perusahaan tidak hanya dunia perbankan. Definisi mudahnya ini terjadi ketika perusahaan atau bank melakukan hubungan kontrak antara manajemen dan pemilik.Apabila bank melakukan kontrak antara pemilik atau pemegang saham dengan agen atau pengurus untuk melakukan pekerjaan atas nama pemilik. Hal yang dimaksud pekerjaan disini bisa berupa wewenang dalam hal pengambilan keputusan. Dalam kenyataannya pasti ada pihak yang memiliki perbedaan kepentingan, dan ada kala dimana manajemen tidak akan selalu bertindak untuk mendahulukan kepentingan pemilik. Hal yang biasa terjadi dari perbedaan kepentingan ini apabila pemilik perusahaan menginginkan perusahaannya dapat maju dalam jangka panjang dan dapat terus bertahan dalam industri tetapi dari sisi manajemen terkadang hanya memikirkan jangka pendek yaitu mencapai profit yang sebesar besarnya.

Prinsip dari Good Corporate Governance ini sudah sangat familiar di dalam dunia ekonomi, prinsip ini sering disebut TARIF (Transparency, Accountability, Responsibility, Independency, Fairness). Transparan dalam hal proses pengambilan keputusan;: Transparansi;Informasi yang transparan ini memudahkan investor untuk dapat membuat keputusan terhadap loss atau gain dari investasinya. Informasi transparan yang berupa laporan keuangan ini digunakan oleh investor untuk menganalisis apakah aman jika investor akan berinvestasi; Akuntabilitas, Kejelasan dilihat dari fungsi, struktur, sistem, dan pertanggungjawaban perusahaan dan dapat diakses oleh para stakeholder yang dapat membuktikan bahwa perusahaan berimbang dan dapat dipertanggung jawabkan sehingga dapat terciptanya tata kelola perusahaan baik; Responsibilitas, Untuk menciptakan bank yang sehat perlu adanya kesesuaian atau kepatuhan dimana bank tetap berpegang dan bertanggung jawab terhadap aturan perundang undangan.; Independensi, Bank harus dikelola tanpa paksaan atau terinteverensi dari berbagai pihak manapun.; Fairness (Kesetaraan atau Kewajaran) Bank harus memiliki kesetaraan dan keadilan dalam hal pemenuhan hak stakeholders berdasar perjanjian atau perundangan yang berlaku hal ini berlaku ke semua pihak baik yang minoritas atau asing

Mekanisme Good Corporate Governance adalah cara, prosedur, aturan untuk menghasilkan sebuah tata kelola perusahaan yang baik sehingga dapat memberikan 
berbagai keuntungan bagi perusahaan. Aturan ini dapat berupa mengatur bagaimana pihak yang berkepentingan dalam pengambilan keputusan atau wewenang pihak pemegang saham dalam menerima haknya, atau pihak kreditur ataupun karyawan dalam mendapat hak dan kewajibannya sehingga dengan sistem yang telah berlaku maka akan muncul sebuah tata kelola perusahaan yang baik dan terhindar dari berbagai macam konflik yang tidak di harapkan pihak pihak terkait. (Wasld dan Seward, 1990 dalam Arifin 2005). Iskandar dan Chamlao dalam Lastanti (2005) menyatakan bahwa mekanisme dalam pengawasan GCG dibagi menjadi dua kelompok yaitu internal dan eksternal. Mekanisme Internal adalah cara menggendalikan perusahaan dengan menggunakan struktur dan proses internal seperti jumlah dewan direksi, dewan komisaris, maupun komisaris independen. Mekanisme eksternal adalah cara mempengaruhi perusahaan contohnya seperti pengendalian perusahaan dan mekanisme pasar. Seperti dalam penelitian ini akan meninjau mekanisme Good Corporate Governance di lihat dari internal mechanism.

Surat edaran yang dikeluarkan oleh Bank Indonesia kepada semua bank umum konvensional di Indonesia tahun 2013 mengenai pelaksanaan Good Corporate Governance bagi bank umum, untuk meningkatkan kinerja bank dan melindungi stakeholder sesuai dengan peraturan perundang undangan yang berlaku dan nilai nilai etika yang berlaku dalam industri perbankan. Pelaksanaan GCG pada industry perbankan harus berlandaskan kelima prinsip dasar TARIF (Transparency, Accountability, Responsibility, Independency, Fairness). Disamping memastikan bahwa 5 prinsip terlaksana dengan baik, bank juga harus melakukan penilaian sendiri secara berkala dimana harus meliputi sekurang-kurangnya 11 faktor penilaian pelaksanaan GCG :Pelaksanaan tugas dan tanggung jawab Dewan Komisaris,Pelaksanaan Tugas dan tanggung jawab direksi, Kelengkapan dan pelaksanaan tugas komite, Penanganan benturan kepentingan, Penerapan fungsi kepatuhan,Penerapan fungsi audit intern, Penerapan fungsi audit ekstern, Penerapan manajemen resiko, Penyediaan dana kepada pihak terkait dan dana besar, Transparansi kondisi keuangan dan non keuangan bank, laporan pelaksanaan GCG, dan pelaporan internal

Terkadang ada bank yang mengalami masalah internal dalam bank seperti keinginan untuk penetapan bonus yang terlalu tinggi sehingga bank akan menetapkan 
target yang tinggi sehingga akan dilakukannya praktek praktek yang tidak sehat baik dari pihak manajemen maupun dari pegawainya sendiri untuk tercapainya target tersebut. Hal ini perlu dijadikan informasi dalam penilaian pelaksanaan GCG diluar dari 11 faktor disebut. Penilaian faktor GCG dalam peningkatan tingkat kesehatan bank umum berdasarkan CAMELS rating. Komponen dari CAMEL meliputi Capital (Rasio Kecukupan Modal), Asset (Rasio Kualitas Aktiva), Management (Rasio Kualitas Manajemen), Earnings (Rasio Rentabilitas Bank), Liquidity (Rasio Likuiditas Bank). Dalam melaksanakan GCG perlu adanya keberadaan komisaris independen dan pihak independen untuk mendukung dalam pelaksanaan tugas agar tidak terjadinya benturan kepentingan.

Setiap stakeholder pasti menginginkan lembaga yang relevan dengan dirinya memiliki kinerja yang baik. Kinerja adalah bagaimana perusahaan memperoleh pencapaian dari tujuan perusahaan yang dapat diukur melalui standar yang telah ada. Menilai sebuah kinerja bukanlah untuk mengetahui apakah perusahaan mendapatkan keuntungan atau tidak tetapi bertujuan untuk mengetahui seberapa efektif operasional yang telah berlangsung. Melalui pengawasan dan pelaporan dari program yang telah diselesaikan dan bagaimana kemajuan dari perkembangan tujuan yang telah ditetapkan sebelumnya. Penilaian kinerja perbankan tidaklah berbeda dengan perusahaan, menilai kinerja perbankan juga bertujuan untuk melakukan perbaikan dan mengevaluasi sejauh mana kegiatan sudah berlangsung agar bank dapat terus bertahan dan memenangkan pasar persaingan dengan berbagai macam strategi yang ditetapkan perusahaan. Kinerja bank yang baik berarti bank mampu menjaga hubungannya ke setiap stakeholdernya dan mempertahankan atau bahkan menaikan profitabilitasnya sehingga bank dapat terus berkembang dan bertahan dalam pasar persaingan. Apabila kinerja bank baik berarti dapat dikatakan bahwa bank mampu membayar devidennya dengan baik sehingga calon investor dapat semakin tertarik untuk menanam saham di bank tersebut bahkan kepercayaan masyarakat terhadap bank yang bersangkutan dapat terus naik.

Kinerja bank berhubungan dengan tingkat kesehatan seperti yang telah dikatakan diatas, kesehatan bank yang diukur melalui CAMEL rating (Surat Keputusan Direksi Bank Indonesia No. 30/277/KEP/DIR) dapat menggambarkan kinerja bank yang bersangkutan. CAMEL haruslah di sesuaikan dengan standar yang telah ditetapkan oleh 
Bank Indonesia baru dapat dikatakan bahwa bank tersebut masuk dalam kategori bank sehat atau tidak sehat. Bank yang masuk dalam kategori sehat berarti dapat dikatakan bahwa bank memiliki kinerja perbankan yang baik.

Penilaian kinerja perusahaan juga dapat diukur dengan rasio keuangan seperti ROE (Return on Equity), ROI (Return on Investment), PER (Price Earning Ratio), Tobin's Q, ROA (Return on Assets). Dalam penilitian ini alat ukur yang peneliti gunakan adalah alat ukur rasio ROA sebagai dasar mengukur kinerja keuangan bank. Tinggi rendahnya dapat menggambarkan seberapa besar efisiensinya penggunaan modal dan turun atau naiknya pendapatan. Seperti yang dikatakan oleh Copeland dalam Firmansyah, 2006 bahwa ROA digunakan untuk mengukur perusahaan dalam menghasilkan keuntungan operasi dengan total aktiva yang dimiliki.

Menurut penelitian Klapper dan Love (2002) dengan menggunakan variabel penelitian bebasnya corporate governance dan variabel terikat Return on Assets dan tobin's Q hasil dari penelitian ini membuktikan adanya hubungan berpengaruh antara corporate governance dengan kinerja perusahaan yang diukur dengan Return on Assets (ROA) dan Tobin's Q. Dalam penelitian Klapper dan Love ditunjukkan pula bahwa keterkaitan antara perusahaan yang menerapkan Good Corporate Governance dengan Negara yang memiliki lingkungan hokum yang baik akan memperoleh manfaat yang lebih besar. Menurut penelitian Hexana Sri Lastanti (2004) dengan menggunakan variabel penelitian bebasnya ukuran dewan komisaris, kepemilikan terkonsentrasi, dan keputusan institusional dan menggunakan variabel terikatnya Tobin's Q, Return on Assets, dan Return on Equity hasil dari penilitian apabila diukur dengan Tobin's Q menunjukkan adanya hubungan yang berpengaruh antara independensi dewan komisaris dengan nilai perusahaan tetapi apabila diukur dengan ROA dan ROE menunjukkan bahwa tidak berpengaruh dengan nilai perusahaan dan kinerja.

Menurut penelitian Sukamulja (2004) dengan menggunakan variabel bebas ukuran perusahaan, ROA, Lama perusahaan listing di BEJ, CGI diproxikan dengan variabel terikat Tobin's Q dengan hasil penelitian Apabila diukur dengan menggunakan Tobin's Q tidak menunjukkan adanya hubungan berpengaruh dengan variabel bebas.Menurut penelitian Moh Belkhir (2005) dengan menggunakan variabel bebas, Dewan komisaris, variabel Terikat ROA,variabel Kontrol Ukuran bankdengan menggunakan sampel 
penelitian berupa 174 bank dan lembaga simpan pinjam selama 1995-2002 dari hasil dari penelitian Moh Belkhir membuktikan adanya pengaruh yang positif dan signifikan antar variabel.Wulandari (2006) melakukan penelitian dengan menggunakan Variabel Bebas Jumlah direksi, Jumlah independen, DER, Keputusan Manajerial,Variabel Terikat Tobin's Q hasil dari penelitian wulandari adalah DER memiliki pengaruh yang positif terhadap Tobin's Q tetapi variabel lainnya tidak memiliki keterikatan dan pengaruh.

Menurut penelitian Irmalasari (2010) dengan menggunakan Variabel Bebas Pemegang saham pengendali, kepemilikan asing, kepemilikan pemerintah, ukuran dewan direksi, ukuran dewan komisaris, komisaris independen, CAR, auditor eksternal, ukuran bank, Variabel Terikatnya ROA hasil dari penelitian Irmalasari membuktikan adanya pengaruh positif hanya untuk ukuran dewan direksi, CAR, dan auditor eksternal, sedangkan variabel lain tidak berpengaruh terhadap ROA.Menurut penelitian Anton (2012) yang menggunakan Variabel bebas Growth opportunity, CGI, Ukuran perusahaan, Variabel Terikat EVA Momentum. Penelitian Anton membuktikan yang memiliki pengaruh positif terhadap EVA momentum hanya Growth Opportunity sedangkan variabel lain tidak memiliki pengaruh terhadap EVA. Dalam penelitian Christiawan (2015) menggunakan Variabel Bebas Dewan Komisaris, Komisaris Independen, Kepemilikan Manajerial, Ukuran Perusahaan. Variabel Terikat yang di

gunakan ROA hasil dari penelitian Christiawan membuktikan bahwa Komisaris independen dan ukuran perusahaan berpengaruh negatif signifikan terhadap ROA, tetapi variabel lain tidak berpengaruh terhadap ROA.

Penelitian ini bertujuan untuk menguji kembali pengaruh mekanisme GCG yaitu jumlah direksi, dewan komisaris, komisaris independen dan ukuran peruusahaan terhadap kinerja perbankan di Indonesia .

\section{METODE}

Populasi yang digunakan untuk penelitian ini adalah seluruh perusahaan perbankan yang terdaftar di BEI yang terdaftar sejak tahun 2012 sampai dengan 2013 yang berjumlah 29 perusahaan perbankan.Penentuan sampel dilakukan dengan purposive 
sampling dengan kriteria: a) Perusahaan Perbankan yang terdaftar di BEI dan secara berturut-turut terdapat selama periode penelitian (tahun 2012-2015); b)Perusahaan Perbankan yang memiliki data lengkap selama periode penelitian (tahun 2012 sampai dengan 2015) dan dapat diandalkan kebenarannya

Data yang digunakan adalah data sekunder yaitu data laporan keuangan yang dapat diperoleh dari Indonesian Capital Market Directory dan annual report yang didapat dari website www.idx.co.id.

Dalam penelitian ini menggunakan analisis regresi berganda (Multiple Regresion Analysis). Analisis ini digunakan untuk menguji atau untuk mengetahui Good Corporate Governance dan ukuran perusahan terhadap kinerja keuangan perbankan. Model penelitian ini dinyatakan dalam persamaan regresi di bawah ini:

$$
\mathrm{KK}=\mathrm{a}+\mathrm{b}_{1} \mathrm{JD}+\mathrm{b}_{2} \mathrm{UDK}+\mathrm{b}_{3} \mathrm{KI}+\mathrm{b}_{4} \mathrm{Size}+\mathrm{e}
$$

Keterangan: $\mathrm{KK}=$ Kinerja Keuangan Perbankan ; $\mathrm{a}=$ koefisien konstanta; b1-b4 = koefisien regresi; JD =Jumlah direksi; UDK = Ukuran Dewan Komisaris; $\mathrm{KI}=$ Komisaris Independen; Size $=$ Size .

Model regresi yang baik adalah model yang lolos dari uji asumsi klasik (Imam Ghozali,2009). Model regresi yang lolos dari uji asumsi klasik berarti data yang digunakkan tidak terjadi multikolinearitas dan heteroskedastisitas. Model regresi yang lolos dari uji asumsi klasik juga membuktikan bahwa data yang digunakan terdistribusi normal sehingga data dapat digunakan untuk diteliti.Cara untuk mengetahui apakah data yang kita gunakan terdistribusi normal adalah dengan uji statistik. Model regresi yang kita gunakan baik apabila data nya terdistribusi normal dan dengan melakukan uji normalitas kita dapat mengetahui apakah data yang kita gunakan terdistribusi normal atau tidak. Menurut Ghozali, 2001 bahwa uji normalitas dapat bertujuan untuk menguji apakah model regresi yang digunakan dalam penelitian, variabel dependen, indepen, dan dalam penelitian ini juga digunakan variabel kontrol memiliki distribusi normal atau tidak. 
Setelah dilakukan uji asumsi klasik terbukti bahwa data yang ada dan digunakan untuk penelitian telah terdistribusi normal dan tidak terdapat multikolinearitas, heteroskedastisitas dan autokorelasi, sehingga memenuhi syarat untuk dilakukan analisis linear berganda atau disebut multiple regression analysis untuk melakukan pengujian terhadap hipotesis.

Tabel 1

Hasil regresi Linear Berganda

Coefficients $^{\mathrm{a}}$

\begin{tabular}{|c|c|c|c|c|c|c|}
\hline \multirow[b]{2}{*}{ Mode } & & Unstandardize & Coefficients & \multicolumn{2}{|l|}{ Coefficients } & \\
\hline & & B & Std. Error & Beta & $\mathrm{T}$ & Sig. \\
\hline 1 & (Constant) & -1.947 & .831 & & -2.344 & .021 \\
\hline & Jumlah_direksi & .052 & .076 & .117 & .680 & .498 \\
\hline & dewan_komisaris & -.186 & .154 & -.171 & -1.208 & .230 \\
\hline & komisaris_independen & .448 & .166 & .329 & 2.708 & .008 \\
\hline & ukuran_perusahaan & .247 & .119 & .342 & 2.069 & .041 \\
\hline & ndent Variable: ROA & & & & & \\
\hline
\end{tabular}

Sumber: data sekunder diolah, 2016

Persamaan yang dapat terbentuk dari hasil estimasi diatas adalah :

$$
\mathrm{ROA}=0,052 \mathrm{JD}-0,186 \mathrm{DW}+0,448 \mathrm{KI}+0,247 \mathrm{UK}+\mathrm{e}
$$

Setelah dilakukan uji asumsi klasik maka untuk mengetahui apakah persamaan regresi yang kita pertanggungjawabkan itu dapat dilakukan pengujian hipotesis. Analisis regresi Linear berganda selain memiliki tujuan untuk menguji hipotesis juga dapat digunakan untuk mengukur apakah ada pengaruh antara variabel independen dengan variabel dependen. Selain untuk mengukur pengaruh antar variabel juga dapat digunakan untuk mengukur koefisien determinasi model penelitian yang di sebut $\mathrm{R}^{2}$ atau $\mathrm{R}$ square. Untuk mengetahui seberapa besar kinerja keuangan mampu dijelaskan oleh variabel independen yaitu jumlah direksi, dewan komisaris, komisaris independen maupun ukuran perusahaan. Tabel yang mengukur adjusted $\mathrm{R}$ square digunakan untuk 
melihat seberapa jauh kemampuan model regresi dalam menerangkan variabel dependen.

Tabel 2

Nilai R dan Koefisien Determinasi

\begin{tabular}{lcccc}
\multicolumn{4}{c}{ Model Summary } \\
\hline Model & $\mathrm{R}$ & R Square & Square & Estimate \\
1 & $.576^{\mathrm{a}}$ & .332 & .305 & .94524 \\
\hline a. Predictors: (Constant), ukuran_perusahaan, komisaris_independen, \\
dewan_komisaris, Jumlah_direksi
\end{tabular}

Pada tabel 2 ditunjukkan bahwa nilai Adjusted $\mathrm{R}^{2}$ adalah sebesar 0,305 hal ini berarti variabel bebas dalam penelitian ini dapat menjelaskan variabel ROA sebesar 30,5\% dan selebihnya sebesar $69,5 \%$ di tunjukkan melalui faktor faktor lain dari variabel tersebut. Nilai standar error of the estimate memberikan arti bahwa dapat disimpulkan bahwa model regresi dapat digunakan / layak digunakan karena memiliki nilai yang kecil yaitu sebesar 0,945 .

Untuk menunjukkan apakah semua variabel independen yang dimasukkan dalam model mempunyai pengaruh secara bersama sama terhadap variabel dependen sehingga apakah model dapat digunakan untuk memprediksi variabel dependen maka dilakukanlah uji statistik F. Berdasarkan hasil uji F, diperoleh F hitung sebesar 12,536 dengan $\mathrm{F}$ tabel 2,46 dapat dikatakan bahwa $\mathrm{F}$ hitung $>\mathrm{F}$ tabel dengan nilai signifikansi sebesar 0,000. Nilai signifikansi 0,000<0,05 menunjukkan bahwa model regresi yang digunakan dapat digunakan untuk memprediksi kinerja keuangan / model fit.

Uji signifikansi parameter Individual t digunakan untuk membuktikan hipotesis serta dapat digunakan untuk mengetahui apakah variabel independen secara parsial berpengaruh signifikan (nyata) terhadap variabel dependen. Berikut adalah hasil estimasi model:

Tabel 3. Hasil estimasi 


\begin{tabular}{|c|c|c|c|c|c|c|}
\hline \multirow[b]{3}{*}{ Model } & & \multicolumn{5}{|c|}{ Standardized } \\
\hline & & \multicolumn{2}{|c|}{ Unstandardized Coefficients } & \multicolumn{2}{|l|}{ Coefficients } & \multirow[b]{2}{*}{ Sig. } \\
\hline & & B & Std. Error & Beta & $\mathrm{T}$ & \\
\hline \multirow[t]{5}{*}{1} & (Constant) & -1.947 & .831 & & -2.344 & .021 \\
\hline & Jumlah_direksi & .052 & .076 & .117 & .680 & .498 \\
\hline & dewan_komisaris & -.186 & .154 & -.171 & -1.208 & .230 \\
\hline & komisaris_independen & .448 & .166 & .329 & 2.708 & .008 \\
\hline & ukuran_perusahaan & .247 & .119 & .342 & 2.069 & .041 \\
\hline
\end{tabular}

a. Dependent Variable: ROA

Hasil estimasi diatas menunjukkan bahwa jumlah direksi berpengaruh terhadap kinerja keuangan dengan tingkat signifikansi sebesar 0,498>0,05. Hal ini menunjukkan jumlah direksi tidak berpengaruh terhadap Kinerja Keuangan perbankan. Sehingga dapat dikatakan hipotesis yang menyatakan jumlah direksi berpengaruh terhadap Kinerja keuangan ditolak; Demikian juga dengan Dewan komisaris tidak berpengaruh terhadap kinerja keuangan perbankan karena tingkat signifikansi yang diperoleh sebesar 0,23>0,05. Komisaris Independen terbukti berpengaruh terhadap Kinerja keuangan perbankan dengan tingkat signifikansi sebesar 0,008 $<0,05$. Firm Size juga terbukti berpengaruh terhadap Kinerja Keuangan perbankan dengan tingkat signifikansi sebesar $0,041<0,05$.

Berdasarkan dari hasil pengujian regresi linier berganda, menunjukkan bahwa model regresi baik untuk digunakan untuk memprediksi Kinerja Keuangan Perbankan. Berdasarkan hasil pengujian, faktor yang paling dominan dalam mempengaruhi kinerja Keuangan perbankan dalam hal perangkat GCG adalah komisaris independen. Hal itu dapat dilihat dari nilai koefisien regresi yang lebih besar bila dibandingkan dengan variabel lainnya. Sedangkan Kinerja keuangan perbankan mampu dijelaskan oleh variabel independen yaitu jumlah direksi, dewan komisaris, komisaris independen, dan variabel kontrol ukuran perusahaan sebesar 30,2\%, sedangkan sisanya yaitu 69,8\% dijelaskan oleh variabel lain selain variabel bebas yang diteliti dalam penelitian ini.

Berdasarkan analisis data yang telah dilakukan, Jumlah direksi tidak berpengaruh terhadap kinerja keuangan perbankan. Jumlah direksi yang ada dalam kondisi perbankan di indonesia periode tahun 2012-2015 memang tidak seturut dengan 
aturan dari bank indonesia yang menyarankan bahwa jumlah direksi seharusnya berjumlah maksimal 3-4 orang menurut surat edaran bi tahun 2013 tetapi dapat dilihat dalam data bahwa jumlah direksi di perusahaan justru memiliki angka minimal 3 dan maksimal 12 jadi sebagian besar bisa dikatakan tidak mengikuti aturan dari bank indonesia. Apabila jumlah direksi terlalu banyak mengakibatkan perbedaan pendapat yang tinggi atau bisa disebut teori keagenan yang besar. Hasil dari penelitian ini sejalan dengan penelitian Wulandari (2005) bahwa jumlah direksi menjadi tidak memiliki pengaruh karena proses tata kelolanya tidak mengikuti aturan surat bank indonesia tentang jumlah direksi yang telah ditetapkan.

Berdasarkan analisis data di atas, dewan komisaris tidak berpengaruh terhadap kinerja keuangan Dewan komisaris merupakan orang orang yang bertanggung jawab mengawasi perusahaan dari sisi internal dan eksternal perusahaan. Dalam hal ini perusahaan sudah melakukan seperti yang PBI katakann yaitu jumlahnya haruslah kurang dari 4 orang bahkan kalau bisa jumlahnya sama dengan komisaris independen. Hasil ini sesuai dengan penelitian Lastanti (2004) dan Irmalasari (2010) yang mengatakan dewan komisaris tidak berpengaruh terhadap kinerja keuangan perbankan.

Hasil estimasi menunjukkan bahwa Komisaris Independen berpengaruh terhadap Kinerja keuangan perbankan . Tugas komisaris independen yang dimana merupakan sebagai penengah apabila terjadi perselisihan antar para manajer internal sehingga memiliki tugas penuh mengawasi apakah GCG terlaksana dengan baik atau tidak. Apabila GCG terlaksana dengan baik maka dapat pula memberikan pengaruh baik bagi perusahaan yang ditunjukkan melalui jumlah profit yang meningkat. Hasil ini sesuai dengan penelitian Christiawan (2015) yang menyatakan bahwa Komisaris Independen berpengaruh terhadap Kinerja keuangan Perbankan.

Estimasi dari model yang diajukan membuktikan bahwa firm size berpengaruh terhadap Kinerja keuangan perbankan . Hasil ini sesuai dengan penelitian Klapper and Love (2002), Sukamulja (2004), dan Christiawan (2015) yang menyatakan bahwa firm size atau ukuran perusahaan berpengaruh terhadap Kinerja Keuangan Perbankan.

\section{PENUTUP}


Hasil analisis mengenai pengaruh mekanisme GCG terhadap kinerja keuangan perbankan di Indonesia selama periode tahun 2011 - 2015 menghasilkan kesimpulan bahwa : jumlah Direksi tisak berpengaruh terhadap Kinerja keuangan perbankan ; jumlah direksi yang tidak sesuai aturan bank Indonesia yang cukup signifikan tidak dapat membuktikan bahwa jumlah direksi memiliki pengaruh terhadap kinerja keuangan perbankan; Dewan Komisaris tidak berpengaruh terhadap Kinerja keuangan perbankan; Komisaris Independen berpengaruh terhadap Kinerja keuangan perbankan. Sesuai dengan teori bahwa tugas komisaris independen sebagai pengawas apakah berjalan dengan baiknya tata kelola atau GCG dalam perusahaan apabila berjalan dengan baik maka akan menambah profit perusahaan dimana kinerja keuangan perbankan semakin baik. Ukuran Perusahaan berpengaruh terhadap Kinerja keuangan perbankan.

Penelitian ini masih memiliki kelemahan mengingat bahwa nilai koefisien determinasi masih sebesar 30,2\%, menunjukkan bahwa Kinerja keuangan perbankan melalui GCG dapat dijelaskan oleh variabel lainnya. Penelitian selanjutnya sebaiknya mempertimbangkan untuk menambah variabel seperti CAR, auditor eksternal, pemegang saham pengendali, kepemilikan asing, kepemilikan manajerial. Selain itu untuk mendapatkan perbandingan dengan sector lain, peneliti selanjutnya dapat menggunakan sector lain seperti pertambangan, atau property dan real estate.

\section{DAFTAR PUSTAKA}

Arifin, Zaenal. 2005. Hubungan antara Corporate Governance dan Variabel Pengurang Masalah Agensi, "Jurnal Siasat Bisnis. Vol.1, No.1, Juni 2005, Hal, 39-55" Arikunto, Suharsimi. 2002. Metodologi Penelitian. Rineka Cipta. Jakarta Bank Indonesia. 1998. Surat Keputusan Direksi Bank No. 30/277/KEP/DIR tanggal 19 Maret 1998 tentang cara Penilaian Tingkat kesehatan Bank Bank Indonesia, 2000. Peraturan BI No. 2/27/PBI/2000 tentang Bank Umum Bank Indonesia, 2003. Peraturan BI No 5/25/PBI/2003 tentang Penilaian kemampuan dan kepatuhan (Fit and Propper Test) Bank Indonesia, 2006. Peraturan BI No. 8/4/PBI/2006 tentang penerapan GCG bagi bank umum yang telah diubah dengan Peraturan Bank Indonesia No.8/14/PBI/2006 
Bank Indonesia, 2007. Surat Edaran BI No.9/12/DNDP tanggal 30 Mei 2007

tentang Perihal pelaksanaan Good Corporate Governance bagi Bank Umum

Bank Indonesia, 2013. Surat Edaran BI No.30/277/KEP/DIR tentang Surat

keputusan Direksi Bank Indonesia

Bank For International Settlements, Basle Committee on Banking Supervision,

(1998) Framework for Internal Control System in banking organization

Beiner, S.W. Drobetz, F. Schmid dan H. Zimmermann, 2003. Is Board Size An

Independent Corporate Governance Mechanism?

Http://www.wwz.Inibaz.chllcofi/publications/papers/2003/06.03.pdf

Belkhir, Mohamed. 2005. Board Structure, Ownwership Structure and firm

performance: Evidence From Banking, Laboratore Economic di Orleans available at :

http://ssrn.com

Brigham, dan Houston. 2001. Dasar - Dasar Manajemen Keuangan. Salemba Empat. Jakarta.

Brigham,E.F \& M.C. Erhardt. 2005. Financial Management Theory and Practice

$11^{\text {th }}$ Edition, Ohio : South Western

Chan.K. and Chen, Nai-Fu. 1991. Structural and Return Characteristic of Small and Large Firms. The Journal of Finance Vol.XLVI.No.4

Darmawati, Deni dkk. 2005. Hubungan Corporate Governance dan Earning

Managemen. Available online at www.ssrn.com

Faisal. 2005. Analisis Agency Cost, struktur Kepemilikan dan Mekanisme

Corporate Governance, “Jurnal Riset Akuntansi Indonesia”, Vol 8, No 2, Hal 175-190.

Ghozali, Imam. 2011. Aplikasi Analisis Multivariate dengan Program IBM SPSS 19. Semarang: BP Universitas Diponegoro. Semarang.

Gujarati, Damodar.1988. Basic Econometrics. New York. McGraw-Hill Book Company.

Hanafi, Mamduh dan Abdul Halim. 2005. Analisis Laporan Keuangan. UPP AMK YKKPN. Yogyakarta.

Husnan, Suad. 2004. Manajemen Keuangan : Teori dan Penerapan (Keputusan Jangka Panjang). BPFE. Yogyakarta.

Kasmir. 2014. Analisa Laporan Keuangan. Rajawali Pers. Jakarta

Klepper, Leora F. and I. Love. 2002. Corporate Governance, Investor Protection and Performance in Emerging Markets. World Bank Working Paper, http://ssrn.com Latumaerissa, Julius.2011. Bank dan Lembaga Keuangan Lain. Salemba Empat 
Lastanti, Hexana Sri. 2004. Hubungan Struktur Corporate Governance dengan kinerja perusahaan dan reaksi pasar, "Konferensi Nasional Akuntansi : Peran Akuntan dalam Membangun Good Corporate Governance"

Munawir. 2002. Analisis Laporan Keuangan. Edisi Empat. Liberty, Yogyakarta Nawawi, Hadari. 2005. Metode Penelitian Bidang Sosial. Yogyakarta: Gadjah Mada University Press.

Riyanto, Bambang. 2008. Dasar-Dasar Pembelanjaan Perusahaan. BEP.Yogyakarta. Oktapiyani, Desi, 2009. Pengaruh Penerapan Corporate Governance Terhadap

Likuiditas Perbankan Nasional. Skripsi Fakultas Ekonomi Universitas Diponegoro Semarang (Tidak dipublikasikan)

Sari, Irmala, 2010. Pengaruh Mekanisme Corporate Governance Terhadap

Kinerja Perbankan Nasional. Skripsi Fakultas Ekonomi Universitas Diponegoro Semarang (Dipublikasikan)

Sukamulja, Sukmawati. 2004. Good Corporate Governance di sektor Keuangan :

Dampak Good Corporate Governance Terhadap Kinerja Keuangan Vol.8 No.1 Juni 2004 Hal 1-25

Wardhani, Ratna. 2006. Mekanisme Corporate Governance dalam Perusahaan yang mengalami Masalah Keuangan (Financially Distressed

Firms),"Simposium Nasional Akuntansi IX, Padang 23-26 Agustus 2006

www.bi.go.id

www.fcgi.com

www.idx.co.id

WwW.ojk.com 